\title{
THE POLITICAL ECONOMY OF SECURITIZATION: THE CASE OF BOKO HARAM, NigERIA
}

\section{Michael OKWUCHI NWANKPa}

Michael Okwuchi Nwankpa is a doctoral candidate in sociology at the University of Roehampton, United Kingdom. He may be reached at mnwankpa@gmail.com.

\section{Abstract}

Since the abduction in 2014 of 276 high school girls in a remote village, Chibok, in Borno state, Nigeria, the activities of the proscribed group Jama'atu Ahlis Sunna Lidda'awati Wal-Jihad, popularly known as Boko Haram, has received elevated domestic and international attention, as has the Nigerian government's strategy to deal with the group. Criticisms of the government's ineffective handling of the situation have been made by a number of foreign governments, and several of them have offered military, intelligence, diplomatic, and law enforcement assistance to Nigeria. From a political economy perspective, this article presents a critical reading and analysis of the local and international response to Boko Haram. It finds that an interest in the "securitization" of development prevails over a genuine peace and security agenda.

$\mathrm{S}$ ince 2009, Boko Haram has grown to become a deadly terror organization, apparently more than a match for the military power of the Nigerian state. The group now presents a substantial threat to regional security. The Nigerian government and its external partners have responded to the crisis mostly in military terms, as denoted by the proscription of the group as a foreign terrorist organization (FTO) and a declaration of a state of emergency in Boko Haram's northeastern base. Nigeria's security forces have received counterterrorism and counterinsurgency training from the United States and other governments, as well as counterterrorism equipment and funding. Also since 2009, Nigeria's defense budget has increased greatly. Yet all these measures have failed to stop the group from carrying out almost daily attacks within and even outside of Nigeria.

This article investigates the macro- and micro responses to the Boko Haram conflict, looks at the political and economic conditions that have sustained it, and explains the relative lack of success against the group by the emphasis government forces and its allies appear to place on "securitized" development rather than on a more genuine peace and prosperity agenda. The findings indicate that the crisis supports a war economy that is gainful to the group as well as to some corrupt public officials in the government and its armed forces. The conflict is also nurtured by a strong quest for political power between and among Nigeria's leading parties and its northern and southern political elites. Also, external support indirectly and sometimes directly helps to sustain the conflict.

The article proceeds as follows. Starting with an overview of Boko Haram, it then discusses "securitization" and external and internal policy responses to the conflict, respectively. The last section concludes the article.

\section{Boko Haram}

Jama'tu Ahlis Sunna Lidda'awati wal-Jihad (People Committed to the Propagation of the Prophet's Teachings and Jihad), popularly known as Boko Haram, started officially in 2002. Its founder and charismatic leader, Mohammed Yusuf, was motivated to return the generally Islamic beliefs and practices of Nigeria's north to an imagined pristine, pure form by following strict codes prescribed by Prophet Mohammed. Yusuf and his followers were involved with the establishment of Sharia penal codes that started in Zamfara state and spread to Nigeria's other 11 northern states in the wake of the civilian rule of President Obasanjo in 2001. The failure to institutionalize that pristine form of belief, and the corruption of and perceived betrayal by northern political and religious elites, led to initial violent and nonviolent clashes between Boko Haram and local authorities, largely through public preaching and brazen criticism of conventional Islamic doctrines and its scholars and through limited armed clashes with police forces.

But since the extrajudicial killing of Yusuf in 2009, and the heavy-handed approach maintained by Nigerian security forces, Boko Haram has evolved into one of the deadliest terror organization in the world, headed by Abubakar Shekau. Its purported ideology is to impose Shariah law on the secular Nigerian state, and this is now mixed with other political and economic agendas. The group's activities are mainly restricted to its operational base in Nigeria's northeastern states, mainly Borno state, the home of its Kanuri-led leadership. ${ }^{1}$ Boko Haram, however, has demonstrated a capacity to strike outside its base, as shown for instance by attacks in northwestern and northcentral states such as Kaduna, Plateau, and Kogi, in the capital, Abuja, and more recently even in a suspected attack in 
Lagos (a significant state in the southwest). Boko Haram has splinter groups, the most prominent being Jama'atu Ansarul Muslimina fi Biladis Sudan (Vanguard for the Protection of Muslims in Black Africa), popularly called Ansaru. Together with its splinter groups, Boko Haram operates terror cells mainly in Nigeria's north but also in border regions and countries such as Chad, Niger, and Cameroon.

Boko Haram violence has grown from sporadic attacks carried out from motor bikes, to targeted assassinations, kidnapping, bombing of public places using improvised explosive devices (IEDs), to car and suicide bombings. Its attacks on security personnel have become less systematic and civilians are increasingly becoming direct targets. Boko Haram's sourcing of its arsenal has shifted from weapons seized in raids carried out on police stations and military barracks to arms smuggled from crisis-torn Libya, taking advantage of Nigeria's porous borders. Revenue sources include illegal arms deals, ransom for kidnapped foreigners and local elites, rents from local business people and some state governors (to prevent attack on those states), and possibly, donations from other regional terror groups. ${ }^{2}$

Securitized development and macro-securitized responses The end of the cold war in the early 1990s saw a growing interest in the relationship between development (freedom from want) and security (freedom from fear). Already ingrained in the 1948 United Nation's Declaration of Human Rights (UNDHR), development concept also entered the UN's Millennium Development Goals (MDGs), adopted by member states and other international organizations in 2000. That the MDGs entail a security dimension was not formally recognized by the UN General Assembly until 2008.

The freedom from want and fear concepts stem from U.S. President Franklin D. Roosevelt's Four Freedoms speech of 6 January 1941. The other two freedoms are freedom of speech and expression and freedom of religion. ${ }^{3}$ While the latter two were already enshrined in the U.S. Constitution, freedom from want and freedom from fear were new elements, first mentioned by Eleanor Roosevelt in a 1 January 1941 speech, a few day prior to her husband's. The Roosevelts inspired the $\mathrm{UN}$, and the new ideal formed the moral anchor for the development of the UNDHR as reflected in the General Assembly Resolution 217A (1948).

... whereas disregard and contempt for human rights have resulted in barbarous acts which have outraged the conscience of mankind, and the advent of a world in which human beings shall enjoy freedom of speech and belief and freedom from fear and want have been proclaimed the
This article investigates the macro- and micro responses to the Boko Haram conflict, looks at the political and economic conditions that have sustained it, and explains the relative lack of success against the group by the emphasis government forces and its allies appear to place on "securitized" development rather than on a more genuine peace and prosperity agenda. The findings indicate that the crisis supports a war economy that is gainful to the group as well as to some corrupt public officials in the government and its armed forces. The conflict is also nurtured by a strong quest for political power between and among Nigeria's leading parties and its northern and southern political elites. Also, external support indirectly and sometimes directly helps to sustain the conflict.

highest aspiration of the common people. ${ }^{4}$

While freedom from fear signaled a desire to move toward a worldwide reduction of armaments, the notion of freedom from want refers to the provision of economic conditions that guarantee individuals within a state "a decent material standard of living, along with reasonable assurance it will continue (or improve)." 5

Today, however, the ever-growing threat of transnational and international terror has changed the face of development assistance such that development aid is now seen as a security defense strategy, hence the term "securitized development." Securitized development defines a situation whereby development aid is given not so much to alleviate poverty or the material want of the poor, marginalized, and vulnerable, but rather to guarantee and protect the security interests of donors. ${ }^{6}$ The War on Terrorism discourse, following the 11 September 2001 terror attack on the U.S., has played a decisive role in undermining the traditional role of development agencies and nongovernmental organizations. It is now not uncommon to see development intervention overlapping with military intervention, 'often tied to 'rich country interest' [ranging] from drugs control to migration and energy security.",

\section{United Kingdom}

In the United Kingdom, for instance, the International Development Act of 2002 - an Act intended to guarantee that development aid is used solely for poverty reduction-is undermined by the government's integration of development, defense, and intelligence resources into a single, coherent policy. While sounding reasonable, this arrangement has ensured that the Department for International Development (DFID) lost its former independence: It is now part of a new National Security Council. ${ }^{8}$ U.K. development aid thus is diverted to "fragile" states such as Afghanistan, Yemen, Somalia, and Pakistan and used to counter terrorism. Fragile 
states are seen less as places with populations in dire need and more as states that pose potential and substantial security risks or threats.

DFID's activities in Nigeria do not have a direct bearing on the Boko Haram crisis. It was not until July 2013, and at the request of the Nigerian government, that the U.K. proscribed Boko Haram as an FTO. A more direct involvement only occurred after the 14 April 2014 kidnapping of 276 high school girls by Boko Haram, with the U.K., alongside the U.S., China, France, and Israel offering aerial surveillance, drones, intelligence and information sharing, law enforcement, hostage-negotiation experts, development assistance, and special troops assistance. Emphasis is shifted to the security, rather than the development, of Nigeria.

\section{European Union}

The EU also plays a major role in establishing peace and security in Africa. For example, it leads the improvement of the Economic Community for West Africa States (ECOWAS), including training of the ECOWAS peacekeeping force, a task shared with the U.S. Articles 8 to 13 of the Cotonou Partnership Agreement articulate the relationship between the EU and Nigeria. The partnership involves concerns with peace and security. The EU recognizes Nigeria as a major contributor to peace and security in the Sahel region and provides support and training for Nigerian peacekeeping troops.

While the EU's development agenda is prominently highlighted, it conceals a more subtle security objective as evidenced by its preconditions of human rights, rule of law, and governance, and its concern with issues of migration and energy. It would seem that the EU's development policies in Africa have become politicized and securitized to produce "unsettling effects on the objectives of EC (European Community) development policies." While the EU has provided development assistance to help Nigeria deal with the security issues in the Niger Delta region and in some northern states, the only hard stance toward the Boko Haram crisis todate is the proscription of the group as an FTO in June 2014.

\section{United States}

The United States' Africa Command (AFRICOM) established by President G.W. Bush under the Department of Defense (DoD), was set up to mitigate security threats posed by fragile African states. AFRICOM, through the African Coastal and Border Security Program and the Trans-Sahara Counter-Terrorism Partnership, provides military training and border and maritime security in Africa. The U.S. Department of State (DoS) established a U.S.-Nigeria Bi-national Commission in 2010, aimed at improving good governance and transparency, promoting regional cooperation and development, energy reform and investment, and food security and agricultural investment. Nigeria benefits from a DoS Antiterrorism Assistance Program that provides funding, equipment, and training to countries fighting terrorism. The Nigerian government also enjoys the benefits of the DoS Counterterrorist Finance Project, which helps to fight terrorist financing and curtails the flow of funds to Boko Haram. In 2011, the DoS labeled three Boko Haram leaders-Abubakar Shekau, Abubakar Adam Kambar, and Khalid al-Barbaai-as Specially Designated Global Terrorists (SDGT), i.e., "foreign persons that support or otherwise associate with ... foreign terrorists. ${ }^{\text {10 }}$ Finally, in November 2013, DoS blacklisted Boko Haram and Ansaru as FTOs. The U.S. currently leads foreign intervention in the effort at rescuing the 276 girls kidnapped by Boko Haram.

However, the Leahy Vetting Process, under the U.S. Foreign Assistance Act of 1961, requires that the DoS and DoD vet foreign partners for human rights compliance to determine eligibility or continuation of assistance and training of foreign security forces. Starting in 2013 when Human Rights Watch published a report on Nigeria (HRW, 2013), the U.S. has threatened to terminate its support to Nigeria, following the indictment of Nigerian security forces for gross human rights violation in the fight against Boko Haram.

\section{Foreign policy implications}

The escalation of the Boko Haram conflict as measured by the increasing scale of violence in Nigeria (involving high civilian casualties and the use of sophisticated weaponry and tactics), the growing targeting of foreign nationals and interests, and the expansion of the violence into neighboring countries seem to have triggered an international alert. The EU and the U.S. have called for a constructive joint regional counterterrorism policy between Nigeria and its neighbors to check Boko Haram and halt its disruptive capabilities on the Sahel region. (States in the region such as Nigeria, Chad, and Cameroon are of strategic importance to world energy supplies.)

Some successes have been achieved as counterterrorism forces of neighboring countries such as Cameroon have apprehended several Boko Haram members and foiled their operations. There is also evidence of some intelligence sharing and cooperation between Nigerian troops and their counterparts. However, a significant level of mistrust prevails and seems to frustrate the progress of the joint regional counterterrorism cooperation.

Branding Boko Haram as an FTO can help the fight against the group as it can affect its financing and the movement of its members through sanctions including "denial of visas, blocking 
of assets, prosecution of supporters who provide material support or funds, and deportation of members" and inform other countries to proscribe it. ${ }^{11}$ In practice, however, this may have little impact as Boko Haram's sources of funding are largely unconventional, with few ties to the standard banking system for instance. Also, visa denials play little role as members restricted themselves to the Sahel region, needing no visa to travel the vast ungoverned borders of the region. Proscription may have a stronger impact at the domestic level, but only if Nigeria's government shows the political will to prosecute.

The direct assistance offered to the Nigerian government since the schoolgirls' abduction has yielded little. Moreover, the assistance may not be free of securitization if we consider the seeming geopolitical rivalry between the U.S. and China for access and control of Africa's abundant energy resources. China's trade volume in Africa is the highest, having reached USD210 billion in 2013, with the U.S.-Africa trade volume down to just USD85 billion in 2013. ${ }^{12}$ Hence, the first-ever U.S.-Africa trade summit hosted by President Obama in August 2014 perhaps indicates the U.S.'s effort at strengthening its importance in Africa. However, a recent trade deal between the U.S. and Africa may have more to do with U.S. political and security interests in Africa than with trade perse.

Following up on this and on the absence of timely external intervention, particularly the restraint of the DoS in proscribing Boko Haram in 2011, one may conclude that the recent offers of intervention by the U.S., U.K., China, Israel, and France reflect less their interest in helping Nigeria to defeat Boko Haram than their own national and strategic interests (such as Boko Haram's expanding transnational terror ideology and affiliation to other international terror organizations such as the Islamic State and the specific targeting of foreign persons and business interest). Indeed, the Nigerian government and its military have accused the U.S. government of frustrating its counterterrorism effort against Boko Haram. It is, however, unclear if the U.S.'s restraint is based solely on its concern with human rights abuses and perceived corruption in the Nigerian military or more concerned with protecting its own national and strategic interests. Either way, development appears to play a decidedly secondary role.

\section{Political economy and micro-securitized responses}

Economic aspects

The people behind Boko Haram wield enormous power, part of which relates to money. Self-evidently, money is one of the forces that sustains the conflict. Since 2009, Nigeria has seen a ten-fold increase in defense budget allocations, from N100 billion (about USD $\$ 625$ million) in 2010 to and N1 trillion ( USD6.25 billion) in 2014. ${ }^{13}$ Ostensibly, the war against Boko Haram is the main motivation for this increase. In addition, on 25 September 2014, the Senate, amid stiff opposition from lawmakers, mainly from the opposition party, approved President Jonathan's request for a USD1 billion loan, to come in the form of supplies of military hardware (such as helicopter, ships, and armaments), logistics and training of armed forces, and other security services.

Apart from the substantial increase in the defense budget, supplementary security budgets, and external loans, the Nigerian government also receives external funding in the form of military aid. Thus, the U.S. supported the Nigerian government with USD2.2 million toward the building of a counterterrorism infantry unit and USD6.2 million for counterterrorism communication and surveillance equipment. ${ }^{14}$ It is therefore possible that foreign governments and external organizations are contributing to protract the Boko Haram war, with unhelpful consequences. For example, seen from the viewpoint of government forces, external development and military aid in the form of cash follows a top-down approach such that the funds usually do not reach its intended target. Such monies, like the untaxable revenue accruing from primary commodities, fuels greed and corruption and sustains the violent conflict. ${ }^{15}$ Despite ongoing economic reforms in Nigeria, the country is plagued by a massive lack of transparency and accountability. In a public letter, dated 4 December 2013, former central bank Governor, Mallam Sanusi Lamido, revealed that the Nigeria National Petroleum Corporation failed to remit a sum of USD49.8 billion of oil revenue to the central bank (later adjusted to USD10.8 billion after an account reconciliation carried out by the Ministry of Finance). It is therefore not surprising that the military and other law enforcement agencies are underfunded and lacking proper equipment to confront the seemingly superior man- and machine-power of Boko Haram. The unregulated, free flow of cash may have fueled corruption among military commanders who, for selfish gain, divert funds meant for soldiers' salary and for the upgrade of weaponry. This brings in focus the general absence of a transparent system to oversee the purchase of military equipment, explains the low morale among soldiers (there has been more than one mutiny in Maiduguri), and the relative incapacity of the military to face Boko Haram.

Also, the attempt to replicate the Niger Delta amnesty for the case of Boko Haram reproduces the structural violence that generally characterize economic and political policies of the Nigerian government. In his inauguration of the Presidential Committee on Dialogue and Peaceful Resolution of Security Challenges in the North, on 24 April 2013, President Jonathan 
bowed to pressure from mostly northern elites to consider granting amnesty to members of Boko Haram. Underlying his decision was an economic logic that overestimated the success of the Niger Delta amnesty and underestimated the much more ideologically-rooted Boko Haram insurgency. Although the Niger Delta militancy is motivated by genuine grievances and aims at economic self-determination and development of the oil-rich region, the rebellion itself is more opportunistic in that the war economy includes a lucrative kidnapping and illegal oil-bunkering business. The Niger Delta amnesty can thus be seen as a formalization of the economic benefit of armed conflict to interested parties and a pay-off to militants: As long as the militants receive their stipends, there is an uninterrupted flow of oil, and oil revenue, as has been the case since 2009.

Far more than is the case for Boko Haram, the Niger Delta insurgency presents high economic incentives as its activities heavily affect Nigeria's oil-based revenue and pose a substantial threat to the international economy (Nigeria being an important supplier of oil and energy). The volume of external aid and assistance flowing toward the Niger Delta thus far exceeds that given toward Boko Haram (in 2011 alone, the EU's Commissioner for Development announced a total amount of EUR478 million for the Nigerian government going toward the consolidation of peace in the Niger Delta and other development projects).

However, "opportunistic rebellions (such as the Niger Delta insurgency) are even less likely to produce economic and social development than ideologically motivated rebellions," 16 so shifting the Boko Haram conflict toward a Niger Delta-style amnesty is not likely to address the underlying issues. Indeed, with one year to go to the end of the Delta amnesty program (in 2015), and little proof of development in the region, one can begin to see cracks that suggest a continuation of violence in the Niger Delta region. ${ }^{17}$ Hence, the statement that " $[\mathrm{r}] \mathrm{ebel}$ leaders generally do well out of war, but cannot be bought off ex ante by government because they cannot be identified" cannot be more correct when one considers Nigeria's failed attempt to buy off Boko Haram members. ${ }^{18}$ For example, in January 2014 it emerged that the Presidential Committee on Peaceful Resolution of Security Challenges in the North had been negotiating with Boko Haram impostors. On 15 January 2014, three men - Kalama Abba, Baba gana Mallam Saje, and Abba Sadiq - were arraigned in a Maiduguri High Court for claiming to be Boko Haram leaders and defrauding a member of the Committee, Barrister Aisha Wakil, of the sum of N70 million (USD431,886), a payment purportedly for convincing Boko Haram members to lay down their arms and embrace dialogue. There is suspicion that federal government officials and impostors were, and are, working together. ${ }^{19}$ What we see is deep structural violence: The government strategically ignores root causes, choosing to reward violence and hence create a political economy of conflict that becomes cyclical.

That the Niger Delta insurgency is perceived as obeying a higher political economy or levels of economic incentives than the Boko Haram insurgency is evident in the inequitable 2014 Presidential special intervention fund allocated to both conflicts. While N63.2 billion (USD389.9 million) was allocated to about 30,000 ex-Niger Delta militants, a meager sum of N2 billion (USD12.3 million) was allocated to the whole of the crisis-torn northeastern region. This may in part explain the recent escalation of the Boko Haram crisis and its attempt to attack the country's economic base - the oil-rich Niger Delta region - as well as its spread beyond its northeastern base to the southern states. Essentially, Boko Haram seeks to enhance economic incentives to negotiate about political power.

\section{Political aspects}

On 14 May 2013, the federal government, with the approval of the House of Assembly, declared a six-month-long state of emergency in three states (Borno, Adamawa, and Yobe) in the troubled northeast. Despite opposition from mostly northern lawmakers, emergency rule has now been extended twice. This is not the first time emergency rule has been declared in Nigeria, or even by the Jonathan administration. On 31 December 2011, a limited state of emergency was declared in parts of Plateau, Borno, Yobe, and Niger states and included a temporary shutdown of international borders with countries bordering the affected states.

Opposition to a prolongation of emergency rule is based on its perceived ineffectiveness as Boko Haram evidently has become bolder and deadlier and its spate of attacks have resulted in a far greater loss of live and property than before the state of emergency. Governor Nyako of Adamawa state has accused the federal government and the ruling party of intent to commit genocide against the people of the region, citing the bloody Nigerian-Biafra civil war. The governor has been impeached by the Adamawa State House of Assembly and declared wanted for his "treasonable" statement. Similarly, there are ongoing impeachment proceedings brought against the governor of Nassarawa state and governors and deputies in opposition party-controlled states.

The impeachment of Nyako on corruption charges after his open letter is no coincidence, and the proceedings against opposition-controlled states all bear resemblance to the political strategy used by former President Obasanjo. The declaration of emergency rule in Ekiti in 2006 and the prosecution of opposition members using the Economic and 
Financial Crimes Commission (EFCC) set up by President Obasanjo offer a handbook on political gaming in Nigeria. It is interesting to note that just as the case with Obasanjo, all these are happening a year before elections (in 2015).

Before the declaration of the state of emergency, there seemed to exist a seamless synergy among members of the Joint Task Force (JTF), comprising the military, police, and navy, and other security agencies such as custom and immigration. Between 2010 and 2012, Boko Haram was spreading its tentacles beyond the northeast and northcentral regions. For example, in 2011 Boko Haram carried out bomb attacks on the police headquarters and on the UN building in Abuja. The success of the JTF was remarkable as they did not only restrict Boko Haram attacks to the northeast, but pushed the group as far back as the outskirts of the northeast states. ${ }^{20}$

The federal government then declared a state of emergency in the northeast with the aim of stamping out any remaining threat. Also in June 2013, the Nigerian National Assembly and Senate approved the federal government proscription of Boko Haram as a terror organization. But the federal government's decision to consolidate its initial victory through the use of the extensive force that a state of emergency affords and the proscription of the group has, paradoxically, helped to sustain Boko Haram. Considering the level of destruction of lives and properties, due to crimes committed by both the insurgents and the Nigerian forces (since the declaration of state of emergency in the northeast from January to March 2014 alone, over 1,500 people were killed $^{21}$ ), it is valid to question the usefulness of the state of emergency.

Related to the emergency rule is the fear that the military may have been compromised. It is not far-fetched to believe that there is a third column in the security formation. It is obvious that the JTF has lost its seamless coordination of activities and that the security services may have deliberately ignored advance warning of impending attacks by Boko Haram. The lack of coordination among the security forces and their increasing human rights violation explains the reshuffling of service chiefs. It is no secret that President Jonathan's administration has been infiltrated by Boko Haram. The President himself admits it, but what has been referred to as his lack of political will in naming and prosecuting those involved reveals that there are strong "cabals" behind the events. It is likely that these cabals are responsible for sabotaging the government's efforts to fight Boko Haram. It is possible that these same cabals are behind the recent spike in bombings and attacks that have been ascribed to Boko Haram.

Underneath all this lies a power game between northern elite and southern minority interests as the blame game between the ruling party, the People's Democratic Party (PDP), and the opposition party, the All People's Congress (APC), proves. Accusations and counter-accusations between the ruling party and Presidency, on the one hand, and the leaders of the opposition party, on the other, have been flying back and forth.

Although Nigeria is home to a very large number of Muslims-about 53 million, more than in Afghanistan or in Iran - it is yet to have a purely religious political party such as the Muslim Brotherhood in Egypt. ${ }^{22}$ The political parties are a mixture of Christians and Muslims and of people of different ethnic groups. Hence, the mission to impose Shariah law on a secular state such as Nigeria can be interpreted as a political calculation to cause a crisis that will favor the reinstallation of northern regional hegemony which was lost in 1999 when power shifted to the South. Likewise, the campaign by the Christian Association of Nigeria (CAN) to portray the Boko Haram crisis as a religious war, as an attack by Muslims on Christians, may also be seen as a political move to attract the sympathy of foreign governments, especially of Western nations, who tend to display zero tolerance toward Islamic fundamentalism.

The internal crises in the PDP, revolving around issues of zoning, ${ }^{23}$ power rotation, and President Jonathan's second-term ambition, all are familiar issues that confirm the north/south power struggle. Many northerners, and the PDP, have blamed the escalation of the Boko Haram crisis on President Jonathan's campaign for a second term, a desire they perceive to be in violation of the agreement to only one term and a northern-headed presidency in 2015. Inciting public statements made by prominent northern political and traditional leaders further exacerbate the tension and lend some credibility to the argument.

The aforementioned reshuffling of the service chiefs may not only serve as a response to allegations of corruption, human rights violation, and rivalry within and among the forces, but may also be a political statement by President Jonathan to control key institutions as he maneuvers the country toward the 2015 elections. Interestingly, all of the new service chiefs, with the exception of the Chief of Defense Staff, Air Marshall Alex Badeh, who is from Adamawa state (one of the troubled states), are from the south and mainly from minority ethnic groups. For instance, the Chief of Army Staff, Major General Kenneth Tobiah Miniman, hails from President Jonathan's own Ijaw minority group.

\section{Conclusion}

Unlike some established terror organizations such as al-Qaeda and the Taliban, which sport reasonably clear agendas, Boko Haram's goals are diffuse. The shifting pattern in its targets 
and its operational dynamics, including its unconfirmed relations with external terror networks and the full range of its financial sources make it a difficult group to engage. What is not in doubt is the group's capacity to cause serious damage to the Nigerian state and to disrupt the whole of the Sahel region. Its importance is underscored by the growing recognition of its influence on, and relations to, other terror networks such as the Islamic State and Hamas in Gaza. ${ }^{24}$

Despite its deadliness, however, the counterterrorism approach to Boko Haram at the macro and micro level appear to be riddled with securitization rather than be concerned with genuine security. There is growing evidence in support of the strong economic and political motivations that underlie and sustain the violence. While, in a bid to stem perceived sabotage and corruption in the military, several court-marshal proceedings have been opened against mutinous and corrupt military personnel and while funds have been sought to improve the morale and fighting capacity of the military, a massive lack of transparency still prevails and little impact on Boko Haram is seen. Nigeria's government has shown little political will to prosecute high-profile individuals who have been fingered as sponsors of the insurgency. More so, external intervention has yielded negligible results, which has made their intention all the more questionable. As the 2015 elections approach, and with a fresh injection of funds into the counterterrorism effort, one waits to see what short and long term effects any of these efforts will have on the conflict.

\section{Notes}

1. Kanuri is perhaps the dominant ethno-linguistic group or lingua franca of northeastern Nigeria. It belongs to the Saharan linguistic family and is spoken by the Kanuri people (mainly in Borno state and across the Middle Belt states with varying dialects). The Kanuris are originally one with the Kanem people and controlled the ancient Kanem-Borno empire. They are mainly pastoralist.

2. Adibe (2013); Amaliya and Nwankpa (2014).

3. Roosevelt (1941).

4. From the preamble in the United Nation's Declaration of Human Rights (1948).

5. Dumas (2011, p. 13).

6. Van Rooyen and Solomon (2007).

7. Watt (2010).

8. ODI (2011).

9. Hadfield (2007, p. 39).

10. Poling (2013, p. 77).

11. Poling (2013, p. 76).

12. Sun and Rettig (2014).
13. ICG (2014, p. 30 ).

14. Gartenstein-Ross and Vassefi (2012).

15. Collier (2010).

16. Collier and Hoeffler (2006, pp. 18-19).

17. Nwankpa (2014).

18. Quote: Collier and Hoeffler (2006, p. 15).

19. ICG (2014).

20. Interview with a JTF sector commander.

21. AI (2014).

22. Ousman (2004).

23. "Zoning" refers to the policy of the ruling political party in Nigeria (the People's Democratic Party, PDP) whereby elective political positions such as the office of the presidency, vice president, Senate president are assigned in a rotational structure to specific areas among Nigeria's six geopolitical regions for specific periods of time.

24. Prime Minister Netanyahu compared Hamas to Boko Haram.

\section{References}

Adibe, J. 2013. "What Do We Really Know About Boko Haram," pp. 9-15 in I. Mantzikos, ed. Boko Haram: Anatomy of a Crisis. Bristol, UK: e-International Relations.

Amaliya, M. and M. Nwankpa. 2014. "Assessing Boko Haram: A Conversation.” Journal of Terrorism Research. Vol. 5, Iss. 1, pp.81-87.

[AI] Amnesty International. 2014. "Nigeria: More than 1,500 Killed in Armed Conflict in North-eastern Nigeria in Early 2014." London: Amnesty International.

Collier, P. 2010. "Democracy, Development and Violence," in N. Clemen Neumann, ed. Current Issues in Human Rights and International Relations: Papers from the Clemens Nathan Research Centre. Leiden: Martinus Nijhoff. http://dx.doi.org/10.1163/ej.9789004179851.i-276.41

Collier, P. and A. Hoeffler. 2006. "Civil War," pp. 711-739 in T. Sandler and K. Hartley, eds. Handbook of Defense Economics, vol. 2. Amsterdam: Elsevier.

Dumas, L.L. 2011. The Peacekeeping Economy. New Haven, CT: Yale University Press.

Gartenstein-Ross, M. and T. Vassefi. 2012. "Current U.S. Policies toward Nigeria's Boko Haram." Gunpowder and Lead. 11 June 2012. http://gunpowderandlead.org/author/ daveedandtara/.

Hadfield, A. 2007. "Janus Advances? An Analysis of EC Development Policy and the 2005 Amended Cotonou Partnership Agreement." European Foreign Affairs Review. Vol. 12, No. 1, , pp. 39-66.

[HRW] Human Rights Watch. 2013. World Report 2013. Nigeria. http: www.hrw.org/world-report/2013/countrychapters/nigeria/ [accessed 5 May 2014].

[ICG] International Crisis Group. 2014. "Curbing Violence in Nigeria (II): The Boko Haram Insurgency.” Africa Report No. 2163 http://www.crisisgroup.org/en/regions/africa/

The Economics of Peace and Security Journal — ISSN 1749-852X — http://www.epsjournal.org.uk

(C) EPS Publishing, 2015. All rights reserved. For permissions, email: ManagingEditor@epsjournal.org.uk 
west-africa/nigeria/216-curbing-violence-in-nigeria-iithe-boko-haram-insurgency.aspx.

Nwankpa, M. 2014. "The Politics of Amnesty in Nigeria: A Comparative Analysis of the Boko Haram and Niger Delta Insurgencies." Journal of Terrorism Research. Vol. 5, Iss. 1, pp. 67-77.

Ousman, A. 2004. "The Potential of Islamist Terrorism in Sub-Saharan Africa." International Journal of Politics. Culture, and Society. Vol. 18, Nos. 1-2, pp. 65-105. http://dx.doi.org/10.1023/B:IJPS.0000048108.65370.fe

[ODI] Overseas Development Institute. 2011. "Is the UK Securitising its Development Aid?" http://www.odi.org/comment/5654-uk-securitising-its-de velopment-aid.

Poling, C.C. 2013. "U.S Congress and Boko Haram," pp. 73-84 in I. Mantzikos, ed. Boko Haram: Anatomy of a Crisis. Bristol, UK: e-International Relations.

Roosevelt, F.D. 1941. "Annual Message to Congress: The Four Freedoms Speech." 6 January 1941 . http://www.fdrlibrary.marist.edu/pdfs/ffreadingcopy.pdf/

Sun, Y. and M. Rettig. 2014. "American and Chinese Trade with Africa: Rhetoric vs. Reality." The Hill. 5 August 2014. http://hehill.com/blogs/pundits-blog/international/21427 0 -american-and-chinese-trade-with-africa-rhetoric-vs-rea lity [accessed 18 December 2014].

Van Rooyen, J. and H. Solomon. 2007. "The Strategic Implications of the US and China's Engagement Within Africa." Scientia Militaria: South African Journal of Military Studies. Vol. 35, No. 1, pp. 1-27.

Watt, P. 2010. "DFID's Transition from Aid Agency to Development Ministry: What Does Policy Coherence Imply?" in N. Clemen Neumann, ed. Current Issues in Human Rights and International Relations: Papers from the Clemens Nathan Research Centre. Leiden: Martinus Nijhoff.

http://dx.doi.org/10.1163/ej.9789004179851.i-276.43 